\title{
Thermogravimetric study of Chlorella vulgaris for syngas production
}

\begin{abstract}
The present study investigates the thermal degradation behavior of Chlorella vulgaris using a thermogravimetric analyzer (TGA) to explore application as feedstock for syngas production. The biomass was heated continuously from room temperature to $1000{ }^{\circ} \mathrm{C}$ at different heating rates $\left(5,10\right.$ and $\left.20^{\circ} \mathrm{C} \mathrm{min}-1\right)$ under N2/air conditions at a constant flow rate of $25 \mathrm{~mL} \mathrm{min-}$ 1. Experimental results showed that the combustion process of $\mathrm{C}$. vulgaris can be divided into three major phases; (1) moisture removal, (2) devolatilization of carbohydrates, protein and lipids and (3) degradation of carbonaceous material. A degradation rate of $80 \%$ was obtained at the second phase of the combustion process in the presence of air whilst a degradation rate of $60 \%$ was obtained under $\mathrm{N} 2$ atmosphere at the same phase. The biomass was further gasified for syngas production using a Temperature Programmed Gasifier (TPG). The effect of three different process variables, temperature, microalgal loading, and heating rate was investigated. The maximum $\mathrm{H} 2$ production was found at $800{ }^{\circ} \mathrm{C}$ temperature with a biomass loading of $0.5 \mathrm{~g}$. No significant effect of heating rate was observed on $\mathrm{H} 2$ production. The activation energy values, based on the Kissinger method, were evaluated to be $45.38 \pm 0.5 \mathrm{~kJ}$ mol- 1 (1st stage), $61.20 \pm 0.5 \mathrm{~kJ}$ mol- 1 (2nd stage) and $97.22 \pm 0.5 \mathrm{~kJ}$ mol- 1 (3rd stage). The results demonstrate a significant potential for the utilization of the microalgae biomass as feedstock for large-scale production of syngas via gasification.
\end{abstract}

Keyword: Chlorella vulgaris; Microalgae; Biomass; Thermogravimetric analysis; Gasification; Syngas 